\title{
Development of Images-Symbols in the Russian Language (Linguoculturological Aspect)
}

\author{
Tatyana Juvenalevna Schuklina ${ }^{1}$ \\ ${ }^{1}$ Department of the Russian Language and Methods of Teaching, Kazan (Privolzhsk) Federal University, \\ Russian Federation \\ Correspondence: Tatyana Juvenalevna Schuklina, Department of the Russian Language and Methods of \\ Teaching, Kazan (Privolzhsk) Federal University, Kremlyovskaya Street, 18, 420008, Kazan, Russian Federation. \\ E-mail: tatiana21@myrambler.ru
}

Received: January 26, 2015 Accepted: February 23, 2015 Online Published: April 27, 2015

doi:10.5539/ass.v11n9p341 URL: http://dx.doi.org/10.5539/ass.v11n9p341

\begin{abstract}
The article is devoted to linguistic images-symbols as national-specific elements of the Russian language reflecting the peculiar character of the national (Russian) culture, special aspects of national way of thinking and interpretation of the surrounding world. The dependence of images-symbols evolving in the Russian language on the specifics of each historical period in the development of Russian language cultural community is exposed on the grounds of the study being undertaken. It has been established that functioning of images-symbols with the emotive-estimating nature having imaginative-symbolic sense appeared to be the consequence of religious symbolism deprivation in syntagmatic combinations of the ancient syncretism epoch as a result of decomposition in syncretic thinking of a man within the Epichristian period, of change in socio-cultural situation in Ancient Russia, i.e. the rejection of the Church Slavonic nature of language and the implantation of laic principle into the community of medieval-era.
\end{abstract}

Keywords: linguistic images-symbols, imaginative-symbolic system, socio-cultural situation, syntagmatic combinations, national way of thinking, national culture

\section{Introduction}

In the study of language at the end of XX- early XXI centuries, the period of the common process of knowledge anthropologization, having overtaken all fields of scientific cognition, the explicit urge to comprehend linguistic phenomena through the prism of a human being is clearly seen. Both in foreign (Danesi, 2008; Gao, 2006; Jourdan, 2006; Kovecses, 2006) and Russian (Karabulatova et al., 2013; Kolesov, 2006; Fattakhova \& Kulkova, 2014; Bochina \& Miftakhova, 2014; Erofeeva, 2014; Wierzbicka, 1996) linguistics the language is considered as not only a means of communication but as the storage of information about the history, cultural experience and the folk-bearer of language's perception of environment which this nation hands down from generation to generation.

The given article is devoted to considering one of the linguistic and culture-bearing phenomenon reflecting mental and cultural peculiarities of the Russian folk, i.e. imaginative-symbolic system of the Russian language. The object of the study is to look more closely at such words-images as chasha (cup), plod (fruit), svet (light) representing the essential fragments of Russian language vision of the world. The work mission is to determine the nature of the linguistic images-symbols semantic content in view of Russian language cultural community development. The analysis performed is of concern both in theoretical (from the standpoint of specifying scientific notations for language expressing of Russian culture ideas shaping the national linguistic stereotypes in the perception and comprehension of reality) and in practical aspects (from the viewpoint of this work utilization at conducting the college course in cultural linguistics and Lexicology of the Russian language for not only Russian speaking students but for Russian studying foreigners as well, since the description of the imaginative-symbolic system of the language necessarily involves its linguistic-cultural and ethnic-linguistical components). 


\section{Transformation of the Images-Symbols' Semantic Content in the Russian Language}

The study of asynchronical Russian written artifacts revealed that the evolution of the Russian language imaginative system dates back to high antiquity and is stipulated by the specific character of each historical period in the development of Russian cultural community.

\subsection{Images-Symbols in the Ancient Russian Language}

Many of the "contemporary" images-symbols lying at the heart of Russian phraseological units keep traces of the ancient visions of the world. They ascend to antiquity, to the epoch of the ancient syncretism and possess the "mythological roots" found in early Russian texts connected with the ecclesiastic-bookish tradition. Each language unit of such text bore a symbolic meaning and had a double character: its "outer meaning" masque another "cryptic" sense. The symbolic scheme of reality was bespoken by the dual character of the human thinking in Epichristian era. This way of thinking was embodied in the common and principal juxtaposition of "sacral - laic" and was stipulated by the attempts to find in "the temporal" and "of the earth earthy" things and natural phenomena, in the events of the human life and historical events, the symbols and signs of the "eternal", "supertemporal", "spiritual" and "divine (Likhachev, 1987; Kamchatnov, 1998).

The "words" containing in Old Russian texts and denoting various realities such as chasha (cup), plod (fruit), svet (light) represented theologic images-symbols borrowed from Biblical Byzantine authentic manuscripts. They were sacralized and bore the impress of early religious Christian ideas of the world's dual nature, the notions that were incarnated in contraposition of objects in the quality of symbols and the objects understood in the usual non-sacral sense and which performed moralizing and didactive function.

The religious symbolism manifested itself in syntagmatic combinations of these "words" with oppositely connected "words" being associated with correlative notions of sky-ground, good-evil, truth-lies, Christianity-unorthodoxy or godlessness. To explicit these ideological contrapositions such "words" were widely used as svetly - tyomny (light-dark), bely - chyorny (white-black), dobriy - zloy (good-evil), sladkiy - gorkiy (sweet- bitter), lyogkiy - tyazhkiy (easy-hard), etc. (Schuklina, 2014, pp. 638-639). The "words" svetly, sladkiy, lyogkiy were associated with everything positive, divine, holy and truly but tyomny, gorkiy, tyazhkiy were similar to everything negative, godless and vicious.

So, the image of fruit either sweet or bitter emblematized the spiritual character of a man: his purity, moral eminence, obedience to God, immaculacy and, appropriately, his viciousness or depravity, For instance, si zhe med $v$ krovyach polagaet $i$ sledovaet nabdyatshemu plod sladok $i$ ne oran (XIII words, 1875, sh. $82 \mathrm{ob}$ ). Med (meaning christian teaching, christian veracities) sanctifies a man and his soul (symbol - plod, i.e. fruit). Such spiritual perfection (everything best and bright) is associated with sladkiy, hence, plod sladok (the fruit is sweet).

The interpretation of symbolic content of the following syntagms: koren moi gorek no plod moi sladok (Merilo Pravednoe, 1961, sh. 9 ob); nakazanie korenie imeet gorko, a plod sladok (Drevnya russkaya pchela, 1893, sh.55) is based upon antithesis contradistinction. Man's intellectual development is inherent in acquiring true knowledge and perception of the divine truth that is attained through sufferings and self-torture but brings blessing and spiritual amelioration for man.

The fate of man suffering a disaster was compared with the image of cup but saintly life of man following in the way of the Master - sladkaya chasha zhizni with sweet cup of life (sladkaya chasha zhizni). For example, Povezh nam rabam tvoim...otkudu ispi pamyat budushchaya zhizni sladkuyu chashu, otkudu vkusi $i$ vide yako Gospod? (Slovo o zakone i blagodati, 1893, sh. 70). Such an approach to the image of cup dates back to the time of Christ's life and death when he took tortures upon oneself for the love of mankind and all outdoor.

In confessional literature of XI - XIV centuries the use of syntagms in "words" svet (light), svechenie (irradiance), siyanie (shining) was of particularly frequent occurrence. Ancient man held holy fire and light in veneration, everything associated with them was covered with odor of sanctity. But this light was sanctified not only because it was the gift of God. The light in itself is a divine creature living. The light as the representation of something good, as the generalization of something desired has always been contraposed to darkness incarnating everything evil and inimical. This contraposition of light and darkness carried over to the Russian earth from Biblical Byzantine authentic manuscripts was also religious-symbolical: Christianity as a new teaching and everything associated with it was similized to light whereas the darkness was measured up against heathenism, unorthodoxy, godlessness: knowledge is light, ignorance is darkness. Their contrast was still more emphasized by the correlation of "words" being coupled with them: beliy (white), sladkiy (sweet), zlaty svet (golden light), i.e. Christian teaching improving a man spiritually, purifying him and giving moral eminence and salvation in a spirit, and chornaya gorkaya tma (evil bitter darkness), i.e. unchristianlike teaching or ungodliness 
bringing about despiritualization, viciousness or depravity. Like as follows: Sikh molitvami sladkym siyaniem $i$ nas prosvetite (Sluzhebnye minei, 1886, sh. 50), where sladkoe siyanie is a spiritual light, christian doctrine, prosvetite means "spiritually ameliorate and make more morally eminent". In syntagmatic association piece Reche paky svetily sladky imam bozhiya dary predlezhyashcha bratie v mirskiya mesto gorkiya zhldi the formula svetily sladky (the state of spiritual purity and holiness) in the quality of the gifts of God are contraposed to gorkym (vicious mundane) pleasures (zhldi) of the mortal life.

\subsection{Images-Symbols in the Russian Language of the Medieval Era}

In the Middle Ages with a view to changes in social and cultural situation of Russia, i.e. the turn of the tide in the way, the standard and the state of life, with disintegration of syncretical way of thinking and its further development in the human society, deliverance from theology of previous centuries and bringing to the existence the laic principle of community, with elevation of national and cultural identity level it can be observed that desacralization of all spheres of man's life and his surroundings took place. The fact that the things and notions bearing the religious and symbolic-generalized sense in the ancient world have become objectivized is obvious (Schuklina, 2012, p. 48).

Such language units as plod (fruit), svet (light), chasha (cup) having functioned in the traditional Old Russian texts represented theologic images-symbols and having possessed abstractedly high sacral sense lost their ecclesiastic-symbolic colouring in the Medieval era. From its inception the ideological contraposition: sladky svet (sweet light) - gorkaya tma (bitter darkness) was understood as the contrast of something "pure, holy, saintly and divine" and, correspondingly, "dark, vicious, virtueless and diabolical". This ideology borrowed from Biblical Byzantine authentic sources through the use of Old Church Slavonic bookish language is converted in the form of something "good, joyful, safe and positive" from the one hand and "evil, inimical, violent and negative", - from the other hand. The given contraposition appears to be found in many medieval texts connected with the historical events of that period. In the passage "...sveta vo tmu prelagati ne tshchusya i sladkoe gorkoe ne prozyvayu, A se li ubo svet, ili sladko, ezhe rabom vladeti? A se li tma i gorko ezhe ot boga dannomu gosudaryu vladeti...se li ubo gorko i tma, yako ot zlykh predstati i blagaya tvoriti? No se est sladko i svet...sam ne razumevaya, chto sladko $i$ svet, $i$ chto gorko i tma, $i$ inykh pouchaet. I ne se sladko i svet, yako blagikh prestati i zlaya tvoriti mezhdousobnymi branmi i samovolstvom. Vsem yavlenna sut, yako nest svet, no tma i nest gorko" (The first message of tsar Ioann Vasilievich, 1914, sh. 49, 68) the image of boyars-enemies is presented which is founded on contradistinction of something "good and positive" expressed in words sladkiy and svet and of "bad and negative" concentrated in words gorkiy and tma.

In literary monuments of XV- XVII the image of cup gained further development. The Biblical image of cup incarnating man's fate and being presented by Metropolitan Ilarion as early as in XI century was widely used in military narratives of XVII: Zane smertnuyu gorkuyu chashu khotya ispiti (Tolkovaya, 1892, p. 12).

The image of cup-fate (gorkoy) in the historical narratives of XVII century is embodied the tragic destiny of the whole country, the whole nation. For example, in "The Story of the Kazanian Tsardom" the fate of the kazaners beaten by the Russian troops is depicted as follows: Priidosha bo $k$ nam gosti nemalya I nalivayut nam piti gorkuyu chashu smertnuyu, eyu zhe my inogda chaste cherpakhom im, ot nikh zhe nyne sami taya zhe gorkiya pitiya smertnya nevoleyu ispivaem (The Story of the Kazanian Tsardom, 1903, sh. 155).

In counterpart with the image of cup-fate, deathy or Divine cup, the image of chasha-battle, death in the combat, on the fight field (like chasha - battle-feast, wedding, in folk-poetic symbolism): no i pache vozgoresya gnev $i$ yazva na lyudi, $i$ chasha napoeniya gorchaishaya polyni priugotovasya, siirech ostreishii mech na vyi vsekh obesisya ... (New story of the glorious Russian Tsardom, 1891, sh. 296 ob).

\subsection{Images-Symbols in the Russian Language of Our Time}

At the present stage of the Russian language development as a result of desacralization of the images-symbols' semantic content their semantic renovation and re-thinking have come to pass. In modern Russian language the metaphorical image of the cup of sorrow is occurred widely. Chasha is used as the symbol of destiny, lot, being usually hard and unhappy. Variations of this image are diverse but in a generalized sense we can say that chasha zhizni (cup of life) is a measure of life granted to a man, his earthy fortune, his life journey by the way of suffer and joy.

The image of fruit (ploda) symbolizes the profitableness of any learning (but not merely Christ's teaching) though the process of being taught is hard indeed: koren uchenia gorek, no plod sladok (the radix of learning is bitter but the fruit is sweet). 
The image-symbol having become perpetuated in the consciousness of the contemporary Russian man as nomination of light has been materialized into such words as goodness, eternity, purity, revelation, loftiness and life itself. Light impersonates the source of joy and pleasure. So, in the proverb uchenie - svet, a neuchenie - tma (knowledge is light, ignorance is darkness), svet (light) - is knowledge making man possible to deeply perceive the beauty of life, to have more opportunities, whereas tma (darkness) is the life of ignorant people, normally dull and uncheerful, passing in poverty and hard work (Birikh, 1999).

\section{Results}

(1). The images-symbols functioning in the Russian language represent national-specific units of the language reflecting the identity of national (Russian) culture, the peculiar features of the national thinking and world's vision.

(2). The Russian language imaginative system keeps the traces of the concepts behind the ancient internal representations of the world. Many of the "contemporary" images-symbols date back to the epoch of the old times' syncretism and have mythological roots being found in Old Russian texts connected with the tradition of Old Church Slavonic books.

(3). The development of the Russian language images-symbols is conditioned by the special features of each historical period in the evolution of the Russian culture linguistic community.

(4). The Russian language imaginative system having possessed a religious symbolism as early as in the epoch of ancient syncretism had been desacralized by the period of Middle Ages and acquired the other - more "real" content. The language does not simply preserve "anachronisms" of mythological representations but semantically renovates and re-thinks them. The effect of pushing aside Old Church Slavonic and further establishing laic language appeared to be the deprivation of religious symbolism by syntagmatic combinations and their acquiring the artistic- symbolical sense. At the present stage of the Russian language development they keep functioning as the images-symbols of the emotive- estimating nature possessing artistical meaning and esthetical significance.

\section{Acknowledgements}

The work is performed according to the Russian Government Program of Competitive Growth of Kazan Federal University.

\section{References}

Birikh, A. K., Mokienko, V. M., \& Stepanova, L. I. (1999). Dictionary of Russian phraseology. Saint Pete: Folio-Press.

Bochina, T. G., \& Miftakhova, A. N. (2014). Gender interpretation of man's figure in the Runet. XLinguae, 7(1), $2-14$.

Danesi, D. (2008). Language, Society, and Culture. Canada: Canadian Scholars' Press, Incorporated.

Drevnya russkaya pchela po pergamentnomu spisky (Ancient Russian bee according to pergameneous manuscript). (1893). The work by V. Semyonov. Digest published by the Department of the Russian language and literature of Russian Academy of Science, V.4, Saint Pete, printing house of the Imperial Academy of Science.

Erofeeva, I. V. (2014). Nominalization in linguocultural paradigm of chronicles. Life Science Journal, 11(11), 438-442.

Fattakhova, N., \& Kulkova, M. (2014). The Formation of Paroemiology in Russia and Germany. World Applied Sciences Journal, 31(5), 935-939.

Gao, F. (2006). Language is Culture - On Intercultural Communication. J. Language Linguistics, 5(1), 58-67.

Jourdan, C. (2006). Language, Culture, and Society. Cambridge University Press.

Kamchatnov, A. M. (1998). History and Hermeneutics Slavonic Bible. Moskow: Nauka.

Karabulatova, I. S., Polivara, Z. V., \& Zamaletdinov, R. R. (2013). Ethno-Linguistic Peculiarities of Semantic Perception of Language Competence of Tatar Bilingual Children. World Applied Sciences Journal, 27(Education, Law, Economics, Language and Communication), 141-145. http://dx.doi.org/10.5829/idosi. wasj.2013.27.elelc. 29

Kolesov, V. V. (2006). Russian mentality in language and text. St. Petersburg: St. Petersburg State University.

Kovecses, Z. (2006). Language, Mind, and Culture: A Practical Introduction. Oxford University Press. 
Likhachev, D. S. (1987). Development of Russian literature of X-XVII centuries. Selected Works. Leningrad: Khudozhestvennaya literature.

Liturgical Menaion in November 1097. (1886). Liturgical Menaion in September, October and November in Old Church Slavonic translation according to Russian manuscripts 1095-1097. Publishing House ORYaS at Russian Academy of Science. Saint Pete.

Merilo Pravednoe (The Measure of Justice). (1961). Spelled out on the manuscript of XIV century. Published under the supervision of academician M. N. Tikhomirov. Moscow.

New story of the glorious Russian Tsardom and the great State of Muscovy. (1891). Monuments of the ancient Russian script related to the Time of Troubles. Russian Historical Library. V.13. Saint Pete.

Paleya Tolkovaya, published according to the manuscript made in 1406 in the city of Kolomna. (1892). Work of N.S. Tikhonravov's students. Moscow.

Schuklina, T. Y. (2012). On the role of sociocultural factors in the semantic development of adjectives in Russian language. Bulletin of the Buryat State University, 10(Philology), 47-51.

Schuklina, T. Y. (2014). Binary oppositions as a way of representing the Slavic culture (in the context of the Russian proverbs). Life Science Journal, 11(10), 638-641.

The first message of tsar Ioann Vasilievich to duke A. Kurbsky. (1914). Writings by duke Kurbsky. Russian Historical Library, V.31. Saint Pete.

The Story of the Kazanian Tsardom. (1903). Complete edition of Russian chronicles. V.19. Saint Pete.

The word of the law and blessing said by Metropolitan Ilarion and published according to several manuscripts. (1893). V. I. Sreznevskiy: Musin-Pushkin collection. Saint Pete.

Wierzbicka, A. (1996). Language. Culture. Cognition. Moskow: Russian dictionaries.

XIII words by Gregory the Theologian in the Old Slavonic translation according to the manuscript kept in Public Library of XI century. (1875). Publishing House ORYaS at Russian Academy of Science. Saint Pete.

\section{Copyrights}

Copyright for this article is retained by the author(s), with first publication rights granted to the journal.

This is an open-access article distributed under the terms and conditions of the Creative Commons Attribution license (http://creativecommons.org/licenses/by/3.0/). 